Article

\title{
The Politics of the Multi-Local in Disaster Governance
}

\author{
Samantha Melis ${ }^{1, *}$ and Raymond Apthorpe ${ }^{2}$ \\ ${ }^{1}$ International Institute of Social Studies, 2546BK The Hague, The Netherlands; E-Mail: melis@iss.nl \\ 2 Royal Anthropological Institute, London, W1T 5BT, UK; E-Mail: araptorp@gmail.com \\ * Corresponding author
}

Submitted: 19 April 2020 | Accepted: 27 May 2020 | Published: 10 December 2020

\begin{abstract}
'Localisation' became the new buzzword after the World Humanitarian Summit in 2016. However, the nature of the commitment to localisation since has been questioned. What is 'the local'? How does localisation work in practice? With little empirical research, generalities in theory and practice have prevailed, preventing a nuanced approach to conceptualising the local. This study aims to build a foundation for the understanding of connotative, nuanced 'locals' and to explore the multiple dimensions of the local in both theory and practice. The methodology of a case study research, with a semi-structured and flexible approach, facilitated the identification of different elements of a locally led response that resounded in each of the cases. Combined with a literature review, this article aims to answer the questions: What underlying assumptions regarding the local are found in localisation rhetoric, and how do multi-local dynamics challenge locally led disaster response in practice? Answering this question necessitates deconstructing the multi-local in theory and critically examining expressions concerning the local in practice. In this study, one dimension of the local that was observed was 'the local as locale,' with the local describing primarily national actors as opposed to the international, without taking local power dynamics into account. The local was also seen in terms of governance, where local-national relations and intranational strife characterised locally led responses, and the national focus excluded local actors who were not usually involved in governance. The local also became a source of legitimation, with local, national and international actors all using the discourse of 'the state in charge' and 'the community knows best' to legitimise their own role as response actors while disputing others' capacities. The multi-local lens provides a perspective with potential to change current practices and contribute to a more transformative agenda.
\end{abstract}

\section{Keywords}

disaster governance; disaster response; humanitarian; localisation; post-conflict

\section{Issue}

This article is part of the issue "The Politics of Disaster Governance" edited by Dorothea Hilhorst (Erasmus University Rotterdam, The Netherlands), Kees Boersma (Vrije Universiteit Amsterdam, The Netherlands) and Emmanuel Raju (University of Copenhagen, Denmark).

(C) 2020 by the authors; licensee Cogitatio (Lisbon, Portugal). This article is licensed under a Creative Commons Attribution 4.0 International License (CC BY).

\section{Introduction}

When the World Humanitarian Summit was concluded in 2016, one of the major goals for the future of humanitarian aid was to be "as local as possible, as international as necessary," meaning that international actors would play only a supportive role and only when needed (United Nations, 2016, p. 30). A concept of localisation rose to the top of the humanitarian agenda following the Summit, with commitments made by interna- tional donors and humanitarian organisations regarding increasing local leadership, building capacity and directing funds to local- and national-level actors to realise these goals, particularly in the field of disaster response.

The prevailing usage of the term 'localisation' suggests that the international is the default and that there should be some shift to the local, or the national as local. Even the criticisms of the humanitarian system-describing it as a top-down, centralised, neoliberal, neocolonial, paternalistic and overpowering 
aid industry that has been shaped by imperial histories (Barnett, 2011; Bräuchler \& Naucke, 2017; Donini, 2012) - maintain a perspective that is quite internationalcentric. Clearly, international donors and humanitarian organisations acting upon the localisation commitments would mean a complete transformation of international humanitarianism. However, given the lack of explicit conceptualisation in the WHS resolution as to how more localisation would improve aid effectiveness, there is much further work on the idea of the local to be done. The local is a strongly multi-valent, even ambiguous, notion that means different things to different people, in different contexts, and for different purposes.

Scholars and practitioners have begun to express concerns about the lack of critical discussion of the practical implications and (im)possibilities of the localisation agenda. These voices have contributed to reflections on locally led responses that recognise current capacities and leadership, shifting power relations and the conceptualisation of the local itself-elements that have often escaped the debate (Apthorpe \& Borton, 2019; Bennett, Foley, \& Sturridge, 2016; DuBois, 2018; Geoffroy \& Grünewald, 2017; Hilhorst, Christoplos, \& Van Der Haar, 2010; Kuipers, Desportes, \& Hordijk, 2019; Roepstorff, 2020; Wall \& Hedlund, 2016). Nevertheless, two major shortcomings remain in the existing literature. First, there is minimal empirically based research analysing the production of the local in cases of locally led disaster response, which has resulted in a lack of attention for the plurality of perspectives of local and non-local actors engaged in disaster response. Second, the discussion has been limited to generalities, failing to take a more nuanced approach to what the local means in practice, in contrast to the literature on the local in peacebuilding, which has been strongly developed (Lederach, 1997; Mac Ginty \& Richmond, 2013; Paffenholz, 2015). This study aimed to contribute to bridging these gaps in previous work.

The study's starting point was the recognition that very different notions about why the local is considered strategic for humanitarian action prevail and the objective of challenging these notions on the basis of locally led disaster response experiences. The empirical section of this article focuses on the post-conflict settings of Nepal, Haiti and Sierra Leone. Given the aim of international actors working in peacebuilding and development of supporting local and national actors with a long-term vision, the local is central for the governance of disasters in these settings. Discussing the different experiences and dimensions of the local in these contexts can serve as a first step towards achieving clarity regarding the challenges of localisation and has the potential to inform a different frame for humanitarian politics.

This article proposes a new concept-'the multilocal.' With this concept, the local in localisation is understood as multiple, comprising a range of locals, each of which tends to be a code for different, if interrelated, meanings and references. The framing of the local in this article is simply an unpacking exercise to identify the range of rationales and options that underly the localisation debate. Unless these options are explicit, sensible communication about localisation remains obscure. Examples of the most common locals include a level in a hierarchy; a locale or a location such as a neighbourhood, district or region; a locus of ideological legitimacy; a source and form of knowledge and other resources such as tradition, heritage, culture or leadership; and a form or focus of governance, including nongovernmental and civil society actors. Importantly, even simple references to 'local,' as in 'the local level,' may connote very different things in terms of, for example, scale, extent, or relations to other levels and components of a polity or economy (e.g., pre-conflict, during conflict and post-conflict). The concept of the local is also included in the ideas of 'local ownership, 'local government,' 'act locally (but think globally),' and 'local knowledge,' each of which itself has multiple meanings, and all of which differ from each other. What is best for the 'national interest' is always contested or contestable (politically and otherwise), and this is equally true for the 'local interest.' Whereas the international is often seen by humanitarians as universal and scientific, the local is viewed in an opposite way. The local also looks different from below than from above. However, in much international humanitarian thinking and writing about intervention and aid, the local is increasingly portrayed as uniform, and 'local' and 'national' tend to be used interchangeably.

This study aims to contribute to answering the following two questions: 1 ) What are the underlying assumptions about the local in localisation? 2) How do multilocal dynamics challenge locally led disaster response in practice? The article illustrates the importance of deconstructing the multiple dimensions and uses of the local in disaster response, with the expressions of politics across spaces and governance levels where the multi-local is produced and contested as one of the main challenges. Here, the deconstruction and empirical application of multiple interconnected locals centres on those that are crucial in disaster response, namely the local as a locale, the local as governance and the local a source of legitimacy. After describing these three key dimensions of the multi-local, we apply the multi-local lens to three empirical case studies of local realities-namely, the locally led responses to the 2015 earthquakes in Nepal, the 2016 Hurricane Matthew in Haiti and the 2017 landslide in Sierra Leone. The article then concludes with a discussion of how a more nuanced framework of the local can contribute to the humanitarian localisation agenda.

\section{2. (De)Constructing the Multi-Local}

This section presents a critical discussion of the different dimensions, or underlying assumptions, of what is meant by 'the local,' as well as the associated risk to a transformative localisation agenda. Here, the focus is on dimensions that are most relevant to locally led disaster 
response: the local as locale, the local as governance and the local as a source of legitimation.

The first dimension of the local-the local as locale or locality-involves boundary setting for the localisation debate. This dimension represents an ostensibly pragmatic approach looking at geographic locations, where disasters are traditionally seen as technocratic problems (Hewitt, 1983), aid effectiveness is among the main reasons for localising aid to actors who are close to the locale (de Torrenté, 2013) and access to localities is often mediated by local actors (Voorst \& Hilhorst, 2017, p. 24). For actors outside the locale, relating to this dimension provides a sense of being 'on the ground' or 'in the field,' references that signify the level closest to the affected location. Localisation in this regard looks at the locale and the actors associated with it from a top-down, external perspective; it strengthens the understanding of the local, in its locality, as a separate, somewhat 'pure' or 'untouched' entity. This dimension of localisation presents local (and national) actors in binary opposition to the international and in terms of 'insiders' and 'outsiders' (Abu-Sada, 2012).

Viewing the local as a single locale leads to a homogeneous vision that overlooks differentiation within the local and thus neglects important questions regarding who is (and who is not) considered part of the local. This essentialisation of the local (Bräuchler \& Naucke, 2017) gives rise to the problem of representation (Appadurai, 1988). There is a risk that this understanding of the local could legitimise (mis)representation of local people by locals who are actually viewed as outsiders. For example, local elites or authorities may be individuals who were able to capture power despite the fact that they do not speak for others in the locale (Pouligny, 2005). Previous work has shown that insider/outsider status is not based only on geographical 'rootedness' in the local or international locales and that a single actor can simultaneously be both an outsider and an insider (Roepstorff \& Bernhard, 2013). Visoka (2018) has demonstrated that these identities are fluid, socially constructed and changing over time. This also relates to how international actors are viewed by locals in a particular locale. Some external actors have had a long-term engagement in the local and have become 'behavioural insiders' (Visoka, 2018) who work closely with insider actors, whereas others, particularly in the humanitarian sector, continue to be perceived as outsiders (Jayawickrama, 2018).

This binary interpretation of the local also ignores how local places and actors are shaped by relations outside the locale. A historical view of international relations demonstrates that colonial, imperial and conflict histories have contributed to the production of disaster vulnerability on both local and national levels (Fatton, 2011; Oliver-Smith, 1994; Wisner, 2012). These external interventions have also become ingrained in everyday socio-political life and are used by different local actors to advance their own goals (Hameiri \& Scarpello, 2018). The interface between the local and the international forms a hybridity, where both are co-constitutive and negotiate contestation and accommodation (Hameiri \& Jones, 2017; Mac Ginty, 2010; Richmond, 2015). These insights construct the locale as a political place that is constantly evolving.

The second dimension pertains to the local as governance. Although disasters may unfold on a local scale, the response is not restricted to actors in the affected locale. From the international perspective, localisation concerns everything that is happening in a country; thus, the national becomes the local. This is encouraged by a state-centric governance (Harvey, 2013). Here, the ambitions of localisation are to decentralise disaster governance, to be more inclusive (Zyck \& Krebs, 2015), to support local ownership (Wall \& Hedlund, 2016) and to increase accountability (International Federation of Red Cross, 2015). A crucial element in accomplishing these aims is the local and national nongovernmental organisations-actors who are already engaged in humanitarian governance.

The desired shift in disaster governance from the international to the local can lead to romanticising the local (Richmond, 2009). Academic literature has cautioned that local governance, like any form of governance, brings together actors who have their own interests and pre-existing power relations. Multiple local government institutions-either formal or informalmay play competing and contentious roles (Hirblinger \& Simons, 2015; Van Leeuwen, Nindorera, Kambale Nzweve, \& Corbijn, 2019) and modes of local governance can co-exist with their own bases of authority and legitimacy (Olivier de Sardan, 2011), especially in postconflict settings where governance arrangements are in flux (Melis, 2018). Furthermore, although national and local governance levels are both included in the local in localisation initiatives, these levels may be at odds with each other. The focus on national governance in disaster response becomes problematic when this level of governance is seen as illegitimate or when local governance is characterised by relatively informal institutions and is not a formal decentralised extension of the national level.

The level or scale of governance that takes the lead in disaster response largely determines the balance of power because it shifts actors' alliances and resources (Hameiri \& Jones, 2017; Hameiri \& Scarpello, 2018; Swyngedouw, 1997; Van Leeuwen et al., 2019). Therefore, the choice of governance level is a political choice that has practical consequences in terms of which actors are included or excluded. When the selected scale of governance remains at national level, it often excludes actors who are not traditionally seen to be involved in governance, such as other public- and private sector actors and religious institutions that are important response actors (Cook, Shrestha, \& Zin, 2018; Gingerich, Beriont, Brodrick, \& Moore, 2017; Jean-Louis \& Klamer, 2016; Nurmala, de Vries, \& de Leeuw, 2018).

One reason for international actors to essentialise and romanticise the local is illustrated by the third dimen- 
sion: the local as (de)legitimation. Because national and local actors play a central role in disaster response policies, their participation, for example in the form of partnerships (Christian Aid et al., 2019), is crucial in the legitimation of external interventions. These external interventions often take the form of capacity building (Fabre, 2017), albeit with insufficient investment (Cohen, Ferguson, Gingerich, \& Scribner, 2016), where local capacities are seen as a resource to be strengthened. The local becomes a site of power (Hirblinger \& Simons, 2015) from which legitimacy is gained.

However, the way capacity is defined thus simultaneously may undermine the legitimacy and equal participation of local actors, who are not consulted on the conceptualisation of what capacity means or which capacities are needed, and whose capacities are not recognised in their own right (Barbelet, 2019). It has been argued that this pattern is part of "structural relations of colonial difference," focusing on the 'incapacity' of local actors (Buba, 2018, p. 3). Setting the agenda and dominating the production of knowledge is a type of power (Foucault, 1984; Maldonado-Torres \& Cavooris, 2017; Mignolo \& Escobar, 2010; Quijano, 2000), and, in the case of these external capacity-building interventions, capacities are pushed to conform to the norms of the international system (Fast, 2017). In this process, discourses matter. The prevailing discourse of the incapacity of local actors is followed by practices that treat local actors as lacking in capacity. Further, the legitimation of humanitarian actors through the humanitarian principles risks delegitimising the local. The humanitarian principles put forward a universalist approach, but many scholars view them as being used as a source of power for top-down paternalistic endeavours (Barnett, 2017). The universalist approach affects the relationship between humanitarian and local actors. National and local authorities, in particular, are often portrayed by humanitarian actors as political, and thus non-neutral, and are seen as 'illegitimate' as humanitarian partners. Humanitarian actors therefore often neglect to support national and local authorities as leaders of the response (Harvey, 2013).

These three dimensions of the local, while not exhaustive, show the danger of loosely interpreting 'the local' in locally led disaster response practice and in scholarly research on localising humanitarian action.

\section{Methodology}

This study is part of a larger research project on disaster response governance in post-conflict settings. For this research, Samantha Melis conducted three case studies of locally led disaster responses in Nepal, Haiti and Sierra Leone. Each case study contributed elements to the creation of wider theory on locally led disaster response governance in post-conflict settings, by using semi-standardised questions while also focusing on the specific contextual elements that each of the cases presented. This facilitated a continuous cycle of action and reflection (Kindon, Pain, \& Kesby, 2007), through which tools and questions were adapted for each of the cases. The small- $\mathrm{N}$ multiple case study is a comparative strategy, which does not compare each case to one another, but lets the resonance between the cases inform the general argument (Lund, 2014). This combines the strengths of an in-depth exploration of a single case study and the analytical broadness of a cross-case study (George \& Bennett, 2005).

In these countries, 273 qualitative interviews and 18 community-based focus group discussions were conducted. A total of 170 of these interviews, and all 18 focus groups, were held with local and national state and non-state actors. The following section will focus primarily on the perspectives expressed by these interviewees. This study does not present a full picture of the multiple dimensions of the multi-local, but rather discusses a number of outcomes resulting from the analysis of the interactions, observations, perspectives and opinions expressed by the research participants. The interviews were semi-structured to allow for a degree of comparability while remaining open and flexible enough to be relevant to the particular contextual dynamics. In each country, the research was completed with the assistance of an academic research partner from either the locality or the capital city. The interviews and focus group discussions were conducted by Samantha Melis, audio-recorded and fully transcribed into English or French. The interviews were anonymised for ethical reasons.

Content analysis was conducted using Nvivo qualitative data analysis software, wherein data was coded to identify themes, from line-by-line coding to more theoretical coding. This grounded approach allowed codes to emerge from the data. The themes addressed the main actor relations, challenges, discourses and social practices of disaster response governance. Discursive frames used by the response actors were identified, but not through a formal discourse analysis. Rather, the analysis was based on both an understanding that data is highly dependent on the interpretations and framings of participants and uncovering how these frames are used in practice.

The case studies presented an opportunity to gain an understanding of the workings of responses that were, to different degrees, locally led. The responses to each of these disasters aimed to support the national and local governance structures, but how did the multiple dimensions of the local find expression in these responses in practice, and what were the most important challenges faced by the local actors?

\section{Perspectives on Multi-Local Disaster Response Governance in Nepal, Haiti and Sierra Leone}

Nepal, Haiti and Sierra Leone, while differing substantially from one another, also share multiple commonalities: Each of these countries has experienced periods of conflict or political crisis, is facing developmental and governance challenges, and is at high risk for disasters. 
Additionally, when disasters have struck in these contexts, the ensuing responses have largely been seen to be 'locally led' (i.e., led within the country). The national governments have led the responses, and, on the surface, international and national actors have supported these efforts. However, the case studies showed that, beneath the surface, there was contestation over roles and legitimacy within and between the national and local levels, complicating locally led responses and challenging the uniform understanding of 'the local' and showing different expressions of 'the local' in practice.

In all three countries, one form of the local that emerged from the interviews was that of the local as locale, where the local connoted primarily national actors (as opposed to international actors) and those closest to the affected population. However, it was not only international actors who were seen as outsiders: The research participants in the affected communities often viewed national and local state actors in a similar way, largely because of the metaphorical-rather than physical-distance between themselves and these actors. This was especially pertinent in Haiti, where people felt 'left behind' by their government. As one member from an agricultural co-operative recounted, "the authorities did not help. That shows how the system is: They do not care about the communities" (personal communication). The discourse of state actors taking advantage of the response to strengthen support from their constituents was strong. In terms of the central state, presidential candidates were described as making promises but not keeping them: "They took advantage of it to politicise. That's the reason he became president" (personal communication).

These kinds of ideas also extended to outsiders in the affected locales themselves; community members did not always accept political elites or local authorities as representatives of the community. In Nepal, people were critical of their local authorities, as was described by the following focus group participant: "The secretary did not give priority to those types of people [poor people, Dalits, women, etc.]. He always listens to powerful persons" (personal communication). Politicians were seen as selfinterested and corrupt and were viewed as having a large role in the response because INGOs were thought to "give responsibility to political parties, but there was no transparency; all are engaging in corruption" (personal communication). The acceptance of local leaders varied, even across neighbouring communities within a country. For example, informal leaders in Sierra Leone who were able to collaborate closely with the national state and international actors increased their legitimacy with community members, whereas another informal leader, who was seen as corrupt, was quickly replaced.

In the locally led responses in the three cases, a myriad of local, national and international actors negotiated aid outcomes, leading to a relatively complex understanding of the local as governance. This understanding underscores how intranational and local-national strife challenges the notion of a uniform local that takes the lead of the response. With the focus on the state as connoting the local, competition between different institutions and authorities ensued. In all three cases, the central state-maintained control over the disaster response, although the coordination of the response was largely decentralised in Nepal and Haiti. In Nepal, intrastate tensions were primarily felt on the local governance level, where local and national politicians needed to establish their legitimacy and where they contended with and put pressure on the local authorities. Tensions were also evident between the local and central state levels; faced with central control, the local authorities tried to negotiate their power by going on strike or by implementing initiatives without permission. In Sierra Leone, state institutions at the central level were in competition with each other over the division of response roles, which, in turn, led to local authorities feeling excluded. In Haiti, tension was seen between the local authorities in the communities and the municipality, with the local authorities' legitimacy largely shaped by the extent to which they were able to withstand politicisation. There was also a schism between the municipality and the central state regarding their respective power, with the central state being seen as providing limited space for local initiatives. In all three cases, authority was continuously being negotiated within the state at different local levels; therefore, from the point of view of local, informal authorities, what would be seen as a more locally led disaster response differed from the national responses that were supported by international actors.

In each of the examined cases, international actors collaborated closely with the state, but the humanitarian-state coordination mechanisms were experienced as exclusionary by local actors who are not usually involved in governance. A multitude of local actors, such as traditional authorities, community stakeholders, religious actors, community-based associations, co-operatives and the private sector, engaged with each other and with aid and state actors in different ways, but these local actors mostly sought to respond outside the humanitarian-state response mechanisms. The private sector, for example, played a major role in the response in Nepal. In Haiti, participants from the private sector saw their strength as providing aid more effectively, compared with INGOs, "as INGOs would be bothered by the bureaucracy behind it because they work with government agencies" (personal communication). For this reason, the private sector actors reported that they mostly engaged with local authorities rather than with national authorities.

In terms of governance, co-governance as such was not seen as sufficient to achieve a more locally led response. International actors were described as often using their power, supported by their resources, to shape the response. State actors had trouble with collaboratively determining the agenda, and smaller NGOs were further limited in their participation. For example, 
in Haiti, the response was generally dominated by international aid actors, and NGOs struggled to access funds, which raised questions regarding the sustainability of the aid system. Local and national NGOs criticised INGOs' funding schemes, noting that these organisations only covered direct implementation costs and not overhead. One participant asserted that the financial structures "do not prioritise the local organisations. They prioritise the internationals" (personal communication). Although locally led disaster response by both the state and local civil society was a primary aim, local actors continued to face challenges with shifting the power centre to the local level.

INGOs, NGOs, and state and local actors all used their relations to the local as legitimation of their roles in the response. Community participants in this study stressed the importance of response actors including them more in the response because 'the community knows best,' and they felt that their knowledge should be valued. Although the discourse of 'the community knows best' and 'we work with the community' was also shared by many of the state actors, division between the perspectives of the state and community members also surfaced. At times, the legitimacy the state drew from the local was accomplished by discrediting the local. In Sierra Leone, state-society mistrust was especially pronounced, with one state official explaining: "Some community people were very deceptive. They were never straightforward" (personal communication). In Nepal and Haiti, this mistrust was geared towards the international actors.

Similarly, a commonly shared sentiment of humanitarians across countries was that 'the state is in charge,' and local and national NGOs were valued as 'partners' who were embedded in society. However, instead of valuing their knowledge, humanitarian actors disputed the capacities of these local and national actors and accused them of corruption. Likewise, local actors criticised the government, but they felt they were not in the position to address these issues. The relationships between local actors and the authorities were conflictual. Particularly in Haiti and Sierra Leone, NGOs experienced difficulties because of the control that the national authorities had over the response. However, NGOs were also able to collaborate relatively well with authorities, especially locallevel authorities, which set them apart from some of their international counterparts. A research participant from an NGO in Haiti recounted that 'several organisations' responses were led by emergency response teams from someplace else: "That would not facilitate that relationship [between aid and state actors]. So it is much easier for us to manage" (personal communication). This point illustrates how the national sometimes functioned to legitimise the local.

\section{Conclusion}

Ambitious claims made for localisation and critical commentary on these, share the common characteristic of speaking of 'the local' as a singular phenomenon. But as illustrated in this article, localisation is far from being a singular idea. Rather it comprises multiple spheres of senses and references, each of which is multidimensional. The multi-local must be considered, recognising the diversity between communities, differences between local and national state and non-state actors, and variation within bodies such as the different layers and institutions of the state.

Understanding the importance of the multi-local leads to the question of what a locally led response would look like when adopting a multi-local lens. This type of locally led response would be achieved mostly by addressing and strengthening communication and cooperation between national and local responders. Instead of international bodies localising a system to be implemented 'below,' local-national integration of disaster governance could be supported. This would also entail opening response governance, with the state taking the lead, to other types of actors who are not usually included, such as private sector and religious institutions. It would also mean integrating formal and informal institutions, with response roles that are clear and defined before disaster strikes. This is important because a disconnect between these actors leads to an ungovernable situation after the initial disaster.

Although 'the local' is imbued with historical power narratives and politics, we cannot-or should notdo away with the term completely. Simply changing the terminology for 'the local' will not automatically do justice to the diversity and power structures within and between different actors that identify, or are constructed, as local. As arguing for a complete overhaul of the discourse is overly ambitious and impractical (and perhaps also not necessarily warranted), a fruitful next step from 'the local' would be recognising the multi-local and being aware of the types of diverging perspectives described in this article.

In light of the above-mentioned dynamics between multiple locals and national actors, the localisation agenda becomes even more complex, raising multiple questions: Who is supported? How? What impact does this have at the local and national levels? Additionally, instead of questioning the legitimacy of local actors, the legitimacy of international actors in the response needs to be re-evaluated. What role can international actors play in bottom-up localisation, respecting the diversity of local actors who are engaged in disaster governance and strengthening-not dismantling - the bonds between them? Addressing these questions is required to critically value a multitude of local actors in the cogovernance of disaster response.

\section{Acknowledgments}

This article was made possible by a $\mathrm{VICl}$ grant from the Netherlands Organisation for Scientific Research (NWO; Grant number: 453-14-01). 


\section{Conflict of Interests}

The authors declare no conflict of interests.

\section{References}

Abu-Sada, C. (Ed.). (2012). In the eyes of others: How people in crises perceive humanitarian aid. New York, NY: MSF-USA.

Appadurai, A. (1988). Introduction: Place and voice in anthropological theory. Cultural Anthropology, 3(1), 16-20.

Apthorpe, R., \& Borton, J. (2019). Disaster-affected populations and "localization": What role for anthropology following the world humanitarian summit? Public Anthropologist, 1(2), 133-155.

Barbelet, V. (2019). Rethinking capacity and complementarity for a more local humanitarian action. London: Humanitarian Policy Group and Overseas Development Institute.

Barnett, M. N. (2011). Empire of humanity: A history of humanitarianism. Ithaca, NY: Cornell University Press.

Barnett, M. N. (Ed.). (2017). Paternalism beyond borders. Washington, DC: Cambridge University Press.

Bennett, C., Foley, M., \& Sturridge, S. (2016). Time to let go: Remaking humanitarian action for the modern era. London: Humanitarian Policy Group and Overseas Development Institute.

Bräuchler, B., \& Naucke, P. (2017). Peacebuilding and conceptualisations of the local. Social Anthropology, 25(4), 422-436.

Buba, I. A. (2018). Aid, intervention, and neocolonial 'development' in Africa. Journal of Intervention and Statebuilding, 13(1), 131-138.

Christian Aid, CARE, Tearfund, ActionAid, CAFOD, \& Oxfam. (2019). Accelerating Localisation through partnerships: Global report. London: Christian Aid.

Cohen, M. J., Ferguson, K., Gingerich, T. R., \& Scribner, S. (2016). Righting the wrong: Strengthening local humanitarian leadership to save lives and strengthen communities. Washington, DC: Oxfam.

Cook, A. D. B., Shrestha, M., \& Zin, B. H. (2018). An assessment of international emergency disaster response to the 2015 Nepal earthquakes. International Journal of Disaster Risk Reduction, 31, 535-547.

de Torrenté, N. (2013). The relevance and effectiveness of humanitarian aid: Reflections about the relationship between providers and recipients. Social Research: An International Quarterly, 80(2), 607-634.

Donini, A. (Ed.). (2012). The golden fleece: Manipulation and independence in humanitarian action (1st ed.). Sterling, VA: Kumarian Press.

DuBois, M. (2018). The new humanitarian basics. London: Humanitarian Policy Group and Overseas Development Institute.

Fabre, C. (2017). Localising the response. Paris: OECD.
Fast, L. (2017). Upending humanitarianism: Questions emerging "from the ground up." London: Humanitarian Policy Group and Overseas Development Institute.

Fatton, R. (2011). Haiti in the aftermath of the earthquake: The politics of catastrophe. Journal of Black Studies, 42(2), 158-185.

Foucault, M. (1984). The order of discourse. In M. J. Shapiro (Ed.), Language and politics. New York, NY: New York University Press.

Geoffroy, V., \& Grünewald, F. (2017). More than the money: Localization in practice. Paris: URD and Trocaire.

George, A. L., \& Bennett, A. (2005). Case studies and theory development in the social sciences. Cambridge, MA: MIT Press.

Gingerich, T. R., Beriont, C., Brodrick, R., \& Moore, D. L. (2017). Local humanitarian leadership and religious literacy: Engaging with religion, faith, and faith actors. Nairobi: Oxfam.

Hameiri, S., \& Jones, L. (2017). Beyond hybridity to the politics of scale: International intervention and 'local' politics: International intervention and 'local' politics. Development and Change, 48(1), 54-77.

Hameiri, S., \& Scarpello, F. (2018). International development aid and the politics of scale. Review of International Political Economy, 25(2), 145-168.

Harvey, P. (2013). International humanitarian actors and governments in areas of conflict: Challenges, obligations, and opportunities. Disasters, 37, 151-170.

Hewitt, K. (1983). The idea of calamity in a technocratic age. In K. Hewitt (Ed.), Interpretations of calamity from the viewpoint of human ecology (pp. 3-30). Boston, MA: Allen \& Unwin.

Hilhorst, D., Christoplos, I., \& Van Der Haar, G. (2010). Reconstruction 'from below': A new magic bullet or shooting from the hip? Third World Quarterly, 31(7), 1107-1124.

Hirblinger, A. T., \& Simons, C. (2015). The good, the bad, and the powerful: Representations of the 'local' in peacebuilding. Security Dialogue, 46(5), 422-439.

International Federation of Red Cross. (2015). World disasters report 2015: Focus on local actors, the key to humanitarian effectiveness. Geneva: International Federation of Red Cross.

Jayawickrama, J. (2018). "If you want to go fast, go alone: If you want to go far, go together": Outsiders learning from insiders in a humanitarian context. Interdisciplinary Journal of Partnership Studies, 5(2). https:// doi.org/10.24926/ijps.v5i2.1309

Jean-Louis, D., \& Klamer, J. (2016). From aid to trade: How aid organizations, businesses, and governments can work together: Lessons learned from Haiti. Grand Rapids, MI: Fresh Strategy Press.

Kindon, S. L., Pain, R., \& Kesby, M. (Eds.). (2007). Participatory action research approaches and methods: Connecting people, participation and place. London and New York, NY: Routledge.

Kuipers, E. H. C., Desportes, I., \& Hordijk, M. (2019). Of locals and insiders: A "localized" humanitarian 
response to the 2017 mudslide in Mocoa, Colombia? Disaster Prevention and Management: An International Journal, 29(3), 352-364.

Lederach, J. P. (1997). Building peace: Sustainable reconciliation in divided societies. Washington, DC: United States Institute of Peace Press.

Lund, C. (2014). Of what is this a case? Analytical movements in qualitative social science research. Human Organization, 73(3), 224-234.

Mac Ginty, R. (2010). Hybrid peace: The interaction between top-down and bottom-up peace. Security Dialogue, 41(4), 391-412.

Mac Ginty, R., \& Richmond, O. P. (2013). The local turn in peace building: A critical agenda for peace. Third World Quarterly, 34(5), 763-783.

Maldonado-Torres, N., \& Cavooris, R. (2017). The decolonial turn. In J. Poblete (Ed.), New approaches to Latin American studies: Culture and power (pp. 111-127). New York, NY: Routledge.

Melis, S. (2018). The fragile state of disaster response: Understanding aid-state-society relations in postconflict settings. In H. G. Brauch, Ú. Oswald Spring, A. E. Collins, \& S. E. Serrano Oswald (Eds.), Climate change, disasters, sustainability transition and peace in the anthropocene (Vol. 25, pp. 67-93). Cham: Springer International Publishing.

Mignolo, W. D., \& Escobar, A. (Eds.). (2010). Globalization and the decolonial option. London New York, NY: Routledge.

Nurmala, N., de Vries, J., \& de Leeuw, S. (2018). Crosssector humanitarian-business partnerships in managing humanitarian logistics: An empirical verification. International Journal of Production Research, 56(21), 6842-6858.

Oliver-Smith, A. (1994). Peru's five-hundred-year earthquake: Vulnerability in historical context. In A. Varley (Ed.), Disasters, development, and environment (pp. 3-48). Chichester: John Wiley and Sons.

Olivier de Sardan, J.-P. (2011). The eight modes of local governance in west Africa (IDS Bulletin No. 42). Sussex: IDS.

Paffenholz, T. (2015). Unpacking the local turn in peacebuilding: A critical assessment towards an agenda for future research. Third World Quarterly, 36(5), 857-874.

Pouligny, B. (2005). Civil society and post-conflict peacebuilding: Ambiguities of international programmes aimed at building 'new' societies. Security Dialogue,
36(4), 495-510.

Quijano, A. (2000). Coloniality of power and eurocentrism in Latin America. International Sociology, 15(2), 215-232.

Richmond, O. P. (2009). The romanticisation of the local: Welfare, culture and peacebuilding. The International Spectator, 44(1), 149-169.

Richmond, O. P. (2015). The dilemmas of a hybrid peace: Negative or positive? Cooperation and Conflict, 50(1), 50-68.

Roepstorff, K. (2020). A call for critical reflection on the localisation agenda in humanitarian action. Third World Quarterly, 41(2), 284-301.

Roepstorff, K., \& Bernhard, A. (2013). Insider mediation in peace processes: An untapped resource? Sicherheit \& Frieden, 31(3), 163-169.

Swyngedouw, E. (1997). Neither global nor local: "Glocalisation" and the politics of scale. In K. R. Cox (Ed.), Spaces of globalization: Reasserting the power of the local. London and New York, NY: Guilford/Longman.

United Nations. (2016). Report of the Secretary-General for the World Humanitarian Summit (No. A/70/709). Washington, DC: United Nations.

Van Leeuwen, M., Nindorera, J., Kambale Nzweve, J.-L., \& Corbijn, C. (2019). The 'local turn' and notions of conflict and peacebuilding: Reflections on local peace committees in Burundi and eastern DR Congo. Peacebuilding, 8(3), 279-299. https://doi.org/ $10.1080 / 21647259.2019 .1633760$

Visoka, G. (2018). Agents of peace. In C. Agius \& D. Keep (Eds.), The politics of identity (pp. 71-89). Manchester: Manchester University Press.

Voorst, R. v., \& Hilhorst, D. (2017). Humanitarian action in disaster and conflict settings: Insights of an expert panel. The Hague: International Institute of Social Studies.

Wall, I., \& Hedlund, K. (2016). Localisation and locallyled crisis response: A literature review. Copenhagen: L2GP.

Wisner, B. (2012). Violent conflict, natural hazards and disaster. In B. Wisner, J. Gaillard, \& I. Kelman (Eds.), The Routledge handbook of hazards and disaster risk reduction (pp. 65-76). London and New York, NY: Routledge.

Zyck, S., \& Krebs, H. (2015). Localising humanitarianism: Improving effectiveness through inclusive action. London: Humanitarian Policy Group and Overseas Development Institute.

\section{About the Authors}

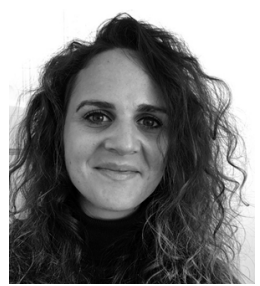

Samantha Melis is a PhD Candidate at the International Institute of Social Studies, The Hague, of Erasmus University Rotterdam. She is currently involved in the research project "When disasters meet conflict," funded by the Netherlands Organisation for Scientific Research. Within this project, she focuses on disaster governance in post-conflict countries. She has previously worked for an international NGO in Burundi and has extensive experience conducting research in conflict affected countries. 


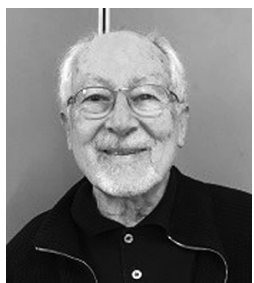

Raymond Apthorpe is currently Hon. Sec., Royal Anthropological Institute, London, and a part-time Visiting Professor at the Centre for Development Studies, University of Cambridge. Earlier he worked for various governmental and non-governmental agencies, on development and humanitarian programme management and evaluation mainly, besides teaching at a number of universities in different parts of the world, the International Institute of Social Studies, the Hague, included. 